International Journal of Diabetology \& Vascular Disease Research (JDVVR)

ISSN:2328-353X

\title{
Sex-based Association of CYP11B2 (-344 C/T) Polymorphism in Indian Type 2 Diabetic Patients
}

Purkait $\mathrm{P}^{1^{*}}$, Roy AG ${ }^{1}$, Halder $\mathrm{K}^{2}$, Suthar $\mathrm{P}^{3}$, Raychaudhuri $\mathrm{P}^{4}$, Bhattacharya $\mathrm{S}^{5}$, B.N. Sarkar ${ }^{1}$, J. M. Naidu ${ }^{6}$

${ }^{1}$ Anthropological Survey of India, 27 Jawaharlal Nehru Road, Kolkata, India

${ }^{2}$ Brahmananda Keshab Chandra College, Bon Hooghly, Kolkata, India.

${ }^{3}$ Anthropological Survey of India, Western Regional Center, Udaipur, Rajasthan, India.

${ }^{4}$ Department of Endocrinology, Calcutta Medical College \& Hospital, Kolkata, India.

${ }^{5}$ Department of Nephrology \& Dialysis, B.P. Poddar Hospital \& Research LTD, Humayun Kabir Sarani, New Alipore, Kolkata, India.

${ }^{6}$ Department of Anthropology, Andhra University, Visakhapatnam, Andhra Pradesh, India.

\begin{abstract}
Background: CYP11B2 gene association studies have been conducted on hypertension, T2DM, and T2DNH in subjects from Caucasian, Asian, and Indian populations. The $-344 \mathrm{C} / \mathrm{T}$ variant is a commonly reported polymorphism of the CYP11B2 gene. The aim of the present study was to investigate the association between the CYP11B2 (-344 C/T) polymorphism and Sex in type 2 diabetic patients in the Indian population.

Methods: The CYP11B2 (-344 C/T) polymorphism was identified by PCR-RFLP and sequencing.

Results: The CYP11B2 gene CC, CT, and TT genotypes accounted for $14.55 \%, 50.00 \%$, and $35.45 \%$ of the male T2DM subjects, $20.55 \%, 34.25 \%$, and $45.21 \%$ of the male controls, $11.46 \%, 54.17 \%$, and $34.38 \%$ of the female T2DM subjects and $11.11 \%, 44.44 \%$, and $44.44 \%$ of the female controls. The CT heterozygote was more frequent among the T2DM subjects than among the controls. The $\mathrm{C}$ allele was most frequent among the male T2DM subjects (39.55\%), followed by the female T2DM subjects (38.54\%), the male controls $(37.67 \%)$, and the female controls $(33.33 \%)$. The T allele was most frequent among the male controls $(62.33 \%)$, followed by the female controls $(66.67 \%)$, the male T2DM subjects $(60.45 \%)$, and the female T2DM subjects $(61.46 \%)$. Overall, the distribution of CYP11B2 genotypes and allele frequencies did not differ significantly.

Conclusion: We did not find any significant association of the CYP11B2 $(-344 \mathrm{C} / \mathrm{T})$ polymorphism with sex in the studied cohort.
\end{abstract}

Keywords: CYP11B2; Sex; T2DM; RFLP; Sequencing; Indian Population.

\section{*Corresponding Author:}

Pulakes Purkait,

DNA Laboratory, Anthropological Survey of India, 27 Jawaharlal Nehru

Road, Kolkata, India.

E-mail: Pulakes.purkait28@gmail.com

Received: March 07, 2015

Accepted: April 02, 2015

Published: May 04, 2015

Citation: Purkait P, et al.,(2015) Sex-based Association of CYP11B2 (-344 C/T) Polymorphism in Indian Type 2 Diabetic Patients. Int J Diabetol Vasc Dis Res, 3(4) 89-93. doi: http://dx.doi.org/10.19070/2328353X-1500018

Copyright: Purkait $\mathbf{P}^{\odot}$ 2015. This is an open-access article distributed under the terms of the Creative Commons Attribution License, which permits unrestricted use, distribution and reproduction in any medium, provided the original author and source are credited.

\section{Introduction}

Aldosterone is an important component of the Renin-Angiotensin-Aldosterone System (RAAS) and plays an important role in controlling blood pressure in the body [36]. RAAS component genes can be candidates for evaluating predisposition to development of hypertension, cardiovascular disease, and progression of renal disease in type 2 diabetes. The CYP11B2 gene encodes a steroid 11/18-beta-hydroxylase that functions in mitochondria in the zona glomerulosa of the adrenal cortex to synthesize the mineralocorticoid aldosterone, and its expression is regulated by angiotensin II and potassium [6]. The CYP11B2 gene contains 9 exons and 8 introns and is located on chromosome $8 \mathrm{q} 22[4,11$, $15,18]$.

The $-344 \mathrm{C} / \mathrm{T}$ variant is a commonly reported polymorphism of the CYP11B2 gene, which is located in the promoter region of the gene [2]. The CYP11B2 gene polymorphism is associated with serum aldosterone level and production [13, 24, 35], blood pressure $[4,30,7,14]$, left ventricular size and mass $[15,34]$, ischemic stroke [25], and essential hypertension. This association with risk of hypertension was found to be confined to male subjects in the south Indian Tamil population [22, 23].

CYP11B2 gene association studies have been conducted extensively in subjects who suffer from hypertension and come from Caucasian, Asian, and Indian populations [1, 4, 7, 10, 19, 22, 26, $29,31,32,33]$ but only a few studies have been conducted in an Indian population with subjects suffering from type 2 diabetes 
(T2DM) [20, 21].

Therefore the aim of the present study is to investigate the association between the CYP11B2 (-344 C/T) polymorphism and sex in type 2 diabetic patients in an Indian population.

\section{Materials \& Methods}

\section{Ethics}

Ethical committee clearance was obtained from the respective medical institutions prior to the recruitment of subjects for this study. Informed consent was obtained from all the participants prior to their recruitment for the study.

\section{Subjects}

This is a sex-based case control study, consisting of 183 males $(\mathrm{T} 2 \mathrm{DM}=110, \mathrm{Con}=73)$ and 141 females $(\mathrm{T} 2 \mathrm{DM}=96, \mathrm{CON}$ $=45$ ). Registered T2DM subjects were recruited at two participating medical institutions, namely (a) Calcutta Medical College (Kolkata), (b) B.P. Poddar Hospital \&Research Centre (Kolkata). Healthy unrelated controls were randomly selected and recruited from local community centers.

\section{Biochemical Analysis}

Venous blood $(10 \mathrm{ml})$ was collected from each individual included in the study for biochemical $(5 \mathrm{ml})$ and genetic analysis $(5 \mathrm{ml})$. Biochemical analyses to determine glucose $(\mathrm{mg} / \mathrm{dl})$, cholesterol $(\mathrm{mg} / \mathrm{dl})$, triglyceride $(\mathrm{mg} / \mathrm{dl})$, HDL cholesterol $(\mathrm{mg} / \mathrm{dl})$, and LDL cholesterol was performed by using automated analyzer (EM 360, TRANSASIA).

\section{CYP11B2 gene analysis}

Approximately $5 \mathrm{ml}$ of venous blood was drawn from each of the subjects in EDTA vials and genomic DNA was extracted from whole fresh blood using standard salting out method using phenol-chloroform [17]. The CYP11B2 (-344 C/T) polymorphism was identified by PCR-RFLP and sequencing. Subjects were genotyped using primers CAGGAGGAGACCCCATGTGA (sense) and CCTCCACCCTGTTCAGCCC (antisense). PCR amplification was performed in a final volume of $10 \mu \mathrm{L}$ reaction mixture containing 50ng of genomic DNA, 20 pmol of each primer, $10 \mathrm{X}$ Taq PCR buffer, $25 \mathrm{mM} \mathrm{MgCl} 2,100 \mathrm{mM}$ of each dNTPs and 0.5 U/uL of Red Taq polymerase. PCR amplification was performed in a DNA thermo cycler (Bio-Rad). PCR was carried out with an initial denaturing time at $95^{\circ} \mathrm{C}$ for $5 \mathrm{~min}$. Then the DNA was amplified for 35 cycles with denaturation at $94^{\circ} \mathrm{C}$ for $1 \mathrm{~min}$, annealing at $69^{\circ} \mathrm{C}$ for $1: 30 \mathrm{~min}$ and extension at $72^{\circ} \mathrm{C}$ for $1: 30 \mathrm{~min}$ and final extension $72^{\circ} \mathrm{C}$ for $10 \mathrm{~min}$. The PCR products were checked by $1 \%$ agarose gel electrophoresis with ethidium bromide staining and directly visualized in UV light.

Restriction fragment length polymorphism (RFLP) analysis was performed by restriction endonuclease Hae III and by incubating at $37^{\circ} \mathrm{C}$ for $3 \mathrm{~h}$ and $30 \mathrm{~min}$. Electrophoresis of the digested samples was done in $2.5 \%$ agarose gel with ethidium bromide staining and analyzed under UV light. The $\mathrm{C}$ alleles were detected as fragments of $202 \mathrm{bp}$ and the T alleles as fragments of $273 \mathrm{bp}$ plus smaller fragments (138bp, 125bp, and $71 \mathrm{bp}$ ) in each case. The genotypes were confirmed by direct sequencing (DNA Analyzer 3730 ABI, Applied Bio system, USA) (Figure 1).

\section{Statistical Analysis}

Data were analyzed using SPSS Version 16.0 (SPSS Inc., Chicago, IL, USA). Data were expressed as Mean \pm SD. Student's t-test and ANOVA test were used to determine differences in means and significance levels. Genotype and allele frequencies of the CYP11B2 gene polymorphism were compared between males and females in type 2 diabetic patients (T2DM) and controls using

Figure 1. Sequence chromatogram for rs1799998 (-344 C/T). Y represents the presence of C and T, Heterozygous CT (Line 1 and 4), line 2 represents Homozygous - CC and line 3 represents Homozygous - TT. Color coding of the peaks: green, adenine (A); blue, cytosine (C); black, guanine (G); red, thymine (T).

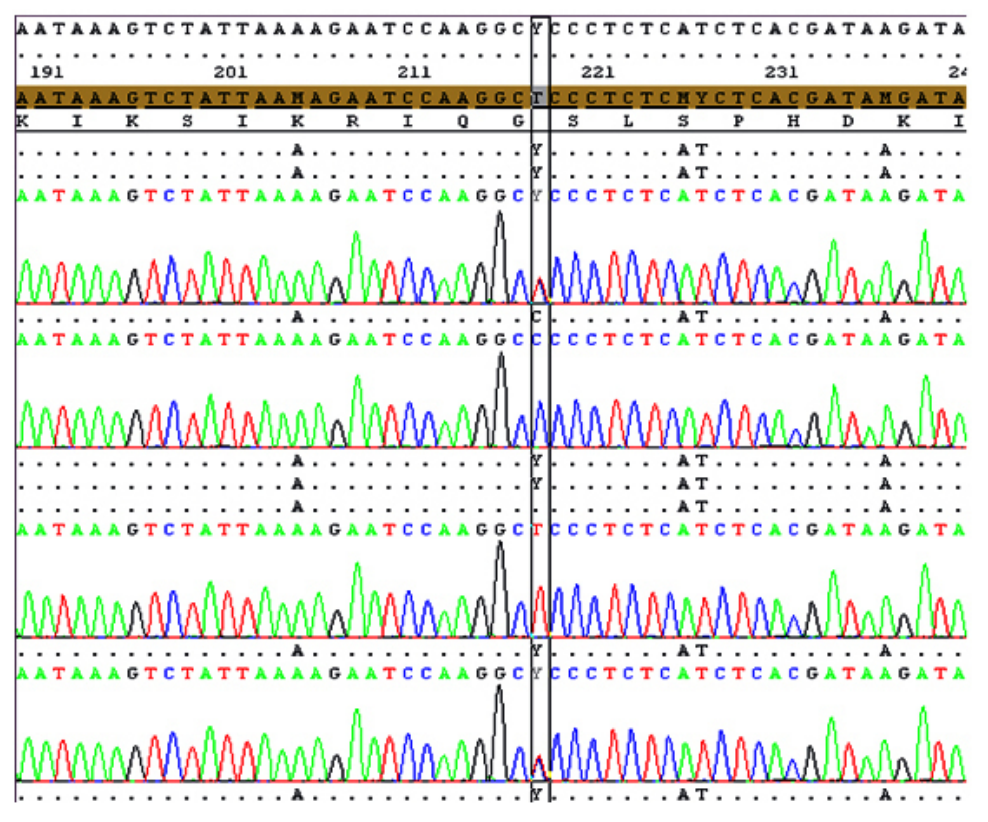


$\chi^{2}$-test. To compare the genotype and allelic distributions between two study groups, the Pearson $\chi^{2}$-test, Odds Ratio (OR), and Risk Ratio (RR) with 95\% confidence interval (CI) were also calculated using an online calculator (http://www.vassarstats.net/odds $2 \times 2$. html?).Statistical significance was assumed at the $\mathrm{P}<0.05$ level.

\section{Results and Discussion}

\section{Clinical characteristics of all subjects}

Baseline clinical characteristics of males and females with type 2 diabetes and healthy controls are presented in Table1. The DBP and HDL values were significant between total male and female subjects $(p<0.05)$, whereas only DBP was significant between T2DM male and T2DM female subjects and HDL was significant between male and female controls $(p<0.05)$. In contrast, no significant difference was observed for age, BMI, SBP, glucose, cholesterol, triglycerides and LDL between males and females with T2DM and controls.

\section{Genotypic and allelic distribution of the CYP11B2 gene pol- ymorphism}

Sex-wise distribution of theCYP11B2 gene genotype along with allele frequencies among subjects with Type 2 diabetes and healthy controls are presented in Table 2. The frequencies of CYP11B2 gene CC, CT, and TT genotypes were $14.55 \%, 50.00 \%$, and $35.45 \%$ for males with T2DM and $20.55 \%$, 34.25\%, and $45.21 \%$ for male controls . Genotype distributions of the CYP11B2 polymorphism differ between T2DM male subjects and male controls but are not statistically significant $\left(\chi^{2}=4.485, \mathrm{p}<0.106\right)$. The CC, CT, and TT genotypes account for $11.46 \%, 54.17 \%$, and $34.38 \%$ of the T2DM female subjects, and $11.11 \%, 44.44 \%$, and $44.44 \%$ of the female controls $\left(\chi^{2}=1.397, \mathrm{p}<0.497\right)$. This table shows that the CT heterozygote occurs more often in the T2DM subjects than in the controls.

The $\mathrm{C}$ allele was a little more frequent among the T2DM male subjects $(39.55 \%)$ than among the male controls (37.67\%) but the $\mathrm{T}$ allele was more frequent among the male controls $(62.33 \%)$ than among the T2DM male subjects $(60.45 \%)$. The table shows that the $\mathrm{C}$ allele was also a bit more frequent among the T2DM female subjects (38.54\%) than among the female controls $(33.33 \%)$. Conversely, the $\mathrm{T}$ allele was more frequent among the female controls $(66.67 \%)$ than among the T2DM female subjects $(61.46 \%)$. Overall, neither the frequencies of the CYP11B2 genotypes nor their allele frequencies differed significantly among the different study groups.

The difference in CYP11B2 genotypes and allele frequencies between any two different study groups along with $\chi^{2}$, $\mathrm{p}$ value, odds ratio, and risk ratio are presented in Table 3. If we look at genotypic combinations and the allele frequencies, we see no significant associations between any of the two studied groups.

In this cross-sectional study, we could not observe any significant differences in genotype and allele frequency of the CYP11B2 (-344 C/T) polymorphism between males and females in T2DM subjects and controls $(\mathrm{p}<0.05)$. Several studies have found an association between this polymorphism and hypertension [5, 27, 30] left ventricle size and mass $[15,28]$, and myocardial infarction $[34,9]$. Studies on the CYP11B2 $(-344 \mathrm{C} / \mathrm{T})$ polymorphism have shown positive $[4,7,33,16,31]$ and negative associations $[26,32$, $10,37]$ with hypertension and other cardiovascular parameters. [8] reported a significant association between the CYP11B2 gene polymorphism and renal insufficiency in hypertensive subjects, and an association with hypertension has been reported in south Indian male subjects [22, 23]. A recent study from Europe in a French population has reported that the CYP11B2 (-344 C/T) polymorphism is associated with T2DM and hypertension and that metabolic syndrome varies by gender [3], whereas Purkait et al., (2013) have reported no association between the CYP11B2 gene polymorphism, T2DNH, and T2DM subjects in an Indian population, probably due to the small sample size.

\section{Conclusion}

We did not find any statistically significant association of CYP11B2 (-344 C/T) polymorphism with Sex (males and females) in Indian T2DM subjects. It is also possible that type 2 diabetic patients with a high risk CYP11B2 genotype may be underrepresented in the present study because of premature cardiovascular-

Table 1. Basic clinical characteristics of males and females with T2DM and male and female controls.

\begin{tabular}{|c|c|c|c|c|c|c|}
\hline \multirow{2}{*}{ Parameters } & \multicolumn{2}{|c|}{ Total Study Group $(\mathrm{N}=324)$} & \multicolumn{2}{c|}{ T2DM $(\mathrm{N}=206)$} & \multicolumn{2}{c|}{ CONTROL $(\mathrm{N}=118)$} \\
\cline { 2 - 7 } & Male $(\mathrm{N}=182)$ & Female $(\mathrm{N}=142)$ & Male $(\mathrm{N}=109)$ & Female $(\mathrm{N}=97)$ & Male $(\mathrm{N}=73)$ & Female $(\mathrm{N}=45)$ \\
\cline { 2 - 7 } & Mean $\pm \mathrm{SD}$ & Mean $\pm \mathrm{SD}$ & Mean $\pm \mathrm{SD}$ & Mean $\pm \mathrm{SD}$ & Mean $\pm \mathrm{SD}$ & Mean $\pm \mathrm{SD}$ \\
\hline Age $(\mathrm{Year})$ & $51.87 \pm 10.62$ & $52.63 \pm 8.77$ & $54.76 \pm 11.50$ & $54.26 \pm 8.99$ & $47.56 \pm 7.33$ & $49.13 \pm 7.19$ \\
\hline BMI $\left(\mathrm{kg} / \mathrm{m}^{2}\right)$ & $24.55 \pm 3.80$ & $24.86 \pm 4.58$ & $24.84 \pm 4.15$ & $24.75 \pm 4.77$ & $24.29 \pm 3.47$ & $24.99 \pm 4.36$ \\
\hline SBP $(\mathrm{mmHg})$ & $136.66 \pm 23.46$ & $135.01 \pm 25.98$ & $143.57 \pm 24.36$ & $142.40 \pm 23.02$ & $126.34 \pm 17.69$ & $119.07 \pm 25.04$ \\
\hline DBP $(\mathrm{mmHg})$ & $86.23 \pm 11.36$ & $83.51 \pm 11.54 *$ & $88.02 \pm 12.07$ & $84.31 \pm 11.23 *$ & $83.56 \pm 9.70$ & $81.80 \pm 12.14$ \\
\hline $\begin{array}{c}\text { Glucose } \\
(\mathrm{mg} / \mathrm{dl})\end{array}$ & $141.29 \pm 66.91$ & $139.64 \pm 46.09$ & $169.75 \pm 85.91$ & $160.38 \pm 51.66$ & $116.34 \pm 25.47$ & $112.91 \pm 13.00$ \\
\hline $\begin{array}{c}\text { Cholesterol } \\
(\mathrm{mg} / \mathrm{dl})\end{array}$ & $164.99 \pm 45.21$ & $172.88 \pm 40.31$ & $168.44 \pm 50.96$ & $179.09 \pm 39.92$ & $159.85 \pm 34.61$ & $159.49 \pm 38.23$ \\
\hline $\begin{array}{c}\text { Triglycerides } \\
(\mathrm{mg} / \mathrm{dl})\end{array}$ & $166.53 \pm 87.47$ & $161.84 \pm 68.52$ & $169.95 \pm 93.72$ & $174.23 \pm 66.53$ & $161.41 \pm 77.54$ & $135.11 \pm 65.72$ \\
\hline HDL $(\mathrm{mg} / \mathrm{dl})$ & $45.06 \pm 16.02$ & $50.14 \pm 17.36 *$ & $49.87 \pm 17.59$ & $51.49 \pm 16.08$ & $37.88 \pm 9.68$ & $47.24 \pm 19.74 *$ \\
\hline LDL (mg/dl) & $95.16 \pm 29.70$ & $97.66 \pm 26.17$ & $94.21 \pm 33.78$ & $98.74 \pm 26.52$ & $96.58 \pm 22.42$ & $95.32 \pm 25.53$ \\
\hline
\end{tabular}

Variables are expressed as the mean \pm SD values; $* \mathrm{P}<0.05$ between males and females 
Table 2. Sex-based distribution of genotype and allele frequencies of the CYP11B2 (-344 C/T) polymorphism in T2DM subjects and controls.

\begin{tabular}{|c|c|c|c|c|}
\hline \multirow{2}{*}{ GENOTYPE } & \multicolumn{2}{|c|}{ MALE } & \multicolumn{2}{c|}{ FEMALE } \\
\cline { 2 - 5 } & $\mathrm{T} 2 \mathrm{DM}$ & $\mathrm{CON}$ & $\mathrm{T} 2 \mathrm{DM}$ & $\mathrm{CON}$ \\
\cline { 2 - 5 } & $\mathrm{N}(\%)$ & $\mathrm{N}(\%)$ & $\mathrm{N}(\%)$ & $\mathrm{N}(\%)$ \\
\hline CC & $16(14.55)$ & $15(20.55)$ & $11(11.46)$ & $5(11.11)$ \\
\hline CT & $55(50.00)$ & $25(34.25)$ & $52(54.17)$ & $20(44.44)$ \\
\hline TT & $39(35.45)$ & $33(45.21)$ & $33(34.38)$ & $20(44.44)$ \\
\hline & $\chi 2=4.485, \mathrm{p}=0.106$ & $\chi 2=1.397, \mathrm{p}=0.497$ \\
\hline ALLELE & \multicolumn{3}{|c}{} & \\
\hline C & $87(39.55)$ & $55(37.67)$ & $74(38.54)$ & $30(33.33)$ \\
\hline T & $133(60.45)$ & $91(62.33)$ & $118(61.46)$ & $60(66.67)$ \\
\hline
\end{tabular}

Table 3. Statistics of genotype and allele distribution of the $C Y P 11 B 2$ gene polymorphism in T2DM subjects and controls.

\begin{tabular}{|c|c|c|c|c|c|c|c|}
\hline Study Group & Statistics & C Vs T & CC Vs TT & $\begin{array}{c}\text { CT Vs } \\
\text { TT }\end{array}$ & $\begin{array}{c}\text { CC Vs } \\
\text { CT }\end{array}$ & $\begin{array}{c}\mathrm{CC}+\mathrm{CT}) \\
\mathrm{Vs} \text { TT }\end{array}$ & $\begin{array}{c}\mathrm{CC} \mathrm{Vs} \\
(\mathrm{CT}+\mathrm{T} T)\end{array}$ \\
\hline \multirow{4}{*}{$\begin{array}{c}\text { T2DM } \\
\text { Vs } \\
\mathrm{CON}\end{array}$} & $x^{2}$ & 0.59 & 0.00 & 4.91 & 2.74 & 3.14 & 0.89 \\
\hline & $\mathrm{P}$ & 0.439 & 1.000 & 0.267 & 0.098 & 0.076 & 0.345 \\
\hline & $\begin{array}{c}\text { OR } \\
(95 \% \mathrm{CI})\end{array}$ & $\begin{array}{c}0.8776(0.6301- \\
1.2224)\end{array}$ & $\begin{array}{c}1.0063 \\
(0.5106- \\
1.9831) \\
\end{array}$ & $\begin{array}{c}0.571 \\
(0.3475- \\
0.9392) \\
\end{array}$ & $\begin{array}{c}1.7613 \\
(0.8968 \\
-3.4593) \\
\end{array}$ & $\begin{array}{c}0.659 \\
(0.4151 \\
-1.0461) \\
\end{array}$ & $\begin{array}{c}1.353 \\
(0.7217- \\
2.5366) \\
\end{array}$ \\
\hline & $\begin{array}{c}\mathrm{RR} \\
(95 \% \mathrm{CI})\end{array}$ & $\begin{array}{c}0.9522 \\
(0.8419-1.0769)\end{array}$ & $\begin{array}{c}1.0017 \\
(0.8321- \\
1.2059) \\
\end{array}$ & $\begin{array}{c}0.7438 \\
(0.5762- \\
0.9601) \\
\end{array}$ & $\begin{array}{c}1.1534 \\
(0.9605 \\
-1.3851) \\
\end{array}$ & $\begin{array}{c}0.7782 \\
(0.5921 \\
-1.0226) \\
\end{array}$ & $\begin{array}{c}1.0463 \\
(0.9493- \\
1.1531) \\
\end{array}$ \\
\hline \multirow{4}{*}{$\begin{array}{l}\text { MALE } \\
\text { T2DM } \\
\text { Vs } \\
\text { CON }\end{array}$} & $\chi^{2}$ & 0.13 & 0.06 & 3.42 & 2.85 & 1.75 & 1.12 \\
\hline & $\mathrm{P}$ & 0.718 & 0.806 & 0.064 & 0.091 & 0.186 & 0.29 \\
\hline & $\begin{array}{c}\text { OR } \\
(95 \% \mathrm{CI})\end{array}$ & $\begin{array}{c}0.924 \\
(0.6009-1.4207)\end{array}$ & $\begin{array}{c}1.108 \\
(0.4767- \\
2.5749) \\
\end{array}$ & $\begin{array}{c}0.5372 \\
(0.2771- \\
1.0416) \\
\end{array}$ & $\begin{array}{c}2.0625 \\
(0.883- \\
4.8176) \\
\end{array}$ & $\begin{array}{c}0.6658 \\
(0.3639 \\
-1.2183) \\
\end{array}$ & $\begin{array}{c}1.5194 \\
(0.6988 \\
-3.3037) \\
\end{array}$ \\
\hline & $\begin{array}{c}\text { RR } \\
(95 \% \mathrm{CI})\end{array}$ & $\begin{array}{c}0.9699 \\
(0.8221-1.1443)\end{array}$ & $\begin{array}{c}1.0314 \\
(0.7992- \\
1.331)\end{array}$ & $\begin{array}{c}0.7292 \\
(0.5251 \\
-1.0126) \\
\end{array}$ & $\begin{array}{c}1.2394 \\
(0.9453 \\
-1.625) \\
\end{array}$ & $\begin{array}{r}0.7843 \\
(0.5489 \\
-1.1207) \\
\end{array}$ & $\begin{array}{c}1.0755 \\
(0.9352 \\
-1.237) \\
\end{array}$ \\
\hline \multirow{4}{*}{$\begin{array}{c}\text { FEMALE } \\
\text { T2DM } \\
\text { Vs } \\
\text { CON }\end{array}$} & $x^{2}$ & 0.71 & 0.22 & 1.39 & 0.03 & 1.32 & 0.00 \\
\hline & $\mathrm{P}$ & 0.399 & 0.639 & 0.238 & 0.499 & 0.251 & 1.000 \\
\hline & $\begin{array}{c}\text { OR } \\
(95 \% \mathrm{CI})\end{array}$ & $\begin{array}{c}0.7973 \\
(0.4712-1.349)\end{array}$ & $\begin{array}{c}0.75 \\
(0.2272- \\
2.4756) \\
\end{array}$ & $\begin{array}{c}0.6346 \\
(0.2974 \\
-1.3542) \\
\end{array}$ & $\begin{array}{c}1.1818 \\
(0.3645- \\
3.8316) \\
\end{array}$ & $\begin{array}{c}0.6548 \\
(0.3177- \\
1.3496) \\
\end{array}$ & $\begin{array}{r}0.9659 \\
(0.3145 \\
-2.9662) \\
\end{array}$ \\
\hline & $\begin{array}{c}\mathrm{RR} \\
(95 \% \mathrm{CI})\end{array}$ & $\begin{array}{c}0.9219 \\
(0.7669-1.1082)\end{array}$ & $\begin{array}{l}0.9375 \\
(0.723- \\
1.2157) \\
\end{array}$ & $\begin{array}{c}0.7765 \\
(0.5158 \\
-1.1688) \\
\end{array}$ & $\begin{array}{c}1.0317 \\
(0.8226- \\
1.2941) \\
\end{array}$ & $\begin{array}{c}0.7734 \\
(0.5042- \\
1.1865)\end{array}$ & $\begin{array}{c}0.9961 \\
(0.8783 \\
-1.1297)\end{array}$ \\
\hline \multirow{4}{*}{$\begin{array}{c}\text { T2DM } \\
\text { Male } \\
\text { Vs } \\
\text { Female }\end{array}$} & $x^{2}$ & 0.04 & 0.21 & 0.13 & 0.53 & 0.03 & 0.43 \\
\hline & $\mathrm{P}$ & 0.841 & 0.647 & 0.718 & 0.467 & 0.862 & 0.512 \\
\hline & $\begin{array}{c}\text { OR } \\
(95 \% \mathrm{CI})\end{array}$ & $\begin{array}{c}0.9587 \\
(0.6446-1.4257)\end{array}$ & $\begin{array}{c}0.8125 \\
(0.3314 \\
-1.992) \\
\end{array}$ & $\begin{array}{c}1.1174 \\
(0.6139 \\
-2.0336) \\
\end{array}$ & $\begin{array}{c}0.7272 \\
(0.3089 \\
-1.7119) \\
\end{array}$ & $\begin{array}{c}1.0487 \\
(0.5904 \\
-1.8626) \\
\end{array}$ & $\begin{array}{c}0.7603 \\
(0.3342 \\
-1.7294) \\
\end{array}$ \\
\hline & $\begin{array}{c}\mathrm{RR} \\
(95 \% \mathrm{CI})\end{array}$ & $\begin{array}{c}0.9837 \\
(0.8426-1.1484)\end{array}$ & $\begin{array}{r}0.9455 \\
(0.7435 \\
-1.2023) \\
\end{array}$ & $\begin{array}{c}1.0687 \\
(0.7464 \\
-1.5302) \\
\end{array}$ & $\begin{array}{c}0.9385 \\
(0.7924 \\
-1.1116) \\
\end{array}$ & $\begin{array}{c}1.0314 \\
(0.7095 \\
-1.4994) \\
\end{array}$ & $\begin{array}{c}0.9651 \\
(0.8685 \\
-1.0725) \\
\end{array}$ \\
\hline \multirow{4}{*}{$\begin{array}{c}\text { CONTROL } \\
\text { Male } \\
\text { Vs } \\
\text { Female }\end{array}$} & $x^{2}$ & 0.45 & 1.05 & 0.45 & 2.21 & 0.01 & 1.76 \\
\hline & $\mathrm{P}$ & 0.502 & 0.306 & 0.502 & 0.137 & 0.920 & 0.185 \\
\hline & $\begin{array}{c}\text { OR } \\
(95 \% \mathrm{CI})\end{array}$ & $\begin{array}{c}0.8273 \\
(0.4766-1.36)\end{array}$ & $\begin{array}{c}0.55(0.1734 \\
-1.7449)\end{array}$ & $\begin{array}{c}1.32 \\
(0.5879- \\
2.9638) \\
\end{array}$ & $\begin{array}{c}0.4167 \\
(0.1292- \\
1.3432) \\
\end{array}$ & $\begin{array}{c}1.0312 \\
(0.4885- \\
2.1769) \\
\end{array}$ & $\begin{array}{c}0.4833 \\
(0.1626- \\
1.4366) \\
\end{array}$ \\
\hline & $\begin{array}{c}\mathrm{RR} \\
(95 \% \mathrm{CI})\end{array}$ & $\begin{array}{c}0.9349 \\
(0.7708-1.134)\end{array}$ & $\begin{array}{c}0.8594 \\
(0.6537- \\
1.1297)\end{array}$ & $\begin{array}{c}1.1379 \\
(0.7763- \\
1.668)\end{array}$ & $\begin{array}{c}0.7813 \\
(0.5731- \\
1.0651)\end{array}$ & $\begin{array}{c}1.0171 \\
(0.673- \\
1.5371)\end{array}$ & $\begin{array}{c}0.8938 \\
(0.7649- \\
1.4366)\end{array}$ \\
\hline
\end{tabular}


related mortality.

\section{Authors' Contribution}

Conceived and designed the experiment: PP, BNS, JMN. Performed the experiment: PP, PCS and AGR. Analyzed the data: PP. Wrote the paper: PP, KH. Collected Sample: PP, PR, SB.

\section{Acknowledgement}

We would like to thank the members of the study populations for their cooperation during data collection. We wish to express our deep gratitude to the Director, Anthropological Survey of India, for his kind permission to initiate the work and also for providing financial support.

\section{References}

[1]. Barbatoa A, Russo P, Siani A, Folkerd EJ, Miller MA, et al. (2004) Aldosterone synthase gene (CYP11B2) C-344T polymorphism, plasma aldosterone, renin activity and blood pressure in a multi-ethnic population. J Hypertens 22: 1895-901.

[2]. Bassett MH, Zhang Y, Clyne C, White PC, Rainey WE (2002) Differential regulation of aldosterone synthase and 11 beta-hydroxylase transcription by steroidogenic factor-1. J Mol Endocrino 128: 125-35.

[3]. Bellili NM, Foucan L, Fumeron F, Mohammedi K, Travert F, et al. (2010) Associations of the $-344 \mathrm{~T}>\mathrm{C}$ and the $3097 \mathrm{G}>\mathrm{A}$ polymorphisms of CY$\mathrm{P} 11 \mathrm{~B} 2$ gene with hypertension, type 2 diabetes, and metabolic syndrome in a French population.Am J Hypertens 23(6): 660-7.

[4]. Brand E, Chatelain N, Mulatero P (1998) Structural analysis and evaluation of the aldosterone synthase gene in hypertension. Hypertension 32: 198204.

[5]. Cheng X, Xu G (2009) Association between aldosterone synthase CYP11B2 polymorphism and essential hypertension in Chinese: a meta-analysis. Kidney Blood Press Res 32: 128- 140

[6]. Clyne CD, Zhang Y, Slutsker L, Mathis JM, White PC, et al. (1997) Angiotensin II and potassium regulate humanCYP11B2 transcription through common cis-elements. Mol Endocrinol 11: 638-649.

[7]. Davies E, Holloway CD, Ingram MC (1999) Aldosterone excretion rate and blood pressure in essential hypertension are related to polymorphic differences in the aldosterone synthase gene CYP11B2. Hypertension 33: 703707.

[8]. Fabris B, Bortoletto M, Candido R (2005) Genetic polymorphisms of the renin-angiotensin-aldosterone system and renal insufficiency in essential hypertension. J Hypertens 23: 309-316.

[9]. Hautanen A, Toivanen P, Manttari M (1999) Joint effects of an aldosterone synthase (CYP11B2) gene polymorphism and classic risk factors on risk of myocardial infarction. Circulation 100: 2213-2218.

[10]. Hengstenberg C, Holmer SR, Mayer B, Löwel H, Engel S, et al (2000) Evaluation of the aldosterone synthase (CYP11B2) gene polymorphism in patients with myocardial infarction. Hypertension 35: 704-9.

[11]. Hilgers K.F, Schmidt BM (2005) Gene variants of aldosterone synthase and hypertension.J Hypertens 23: 1957-1959.

[12]. http://www.vassarstats.net/odds2x2.html?

[13]. Keavney B, Mayosi B, Gaukrodger N (2005) Genetic variation at the locus encompassing 11 - beta hydroxylase and aldosterone synthase accounts for heritability in cortisol precursor (11-deoxycartisol) urinary metabolite excretion. J clin Endocrinol Metab 90: 1072-7.

[14]. Kumar NN, Benjafield AV, Lin RC, Wang WY, Stowasser M, et al. (2003) Haplotype analysis of aldosterone synthase gene (CYP11B2) polymorphisms shows association with essential hypertension. J Hypertens 21: 1331-1337.

[15]. Kupari M, Hautanen A, Lankinen L (1998) Associations between human aldosterone synthase (CYP11B2) gene polymorphisms and left ventricular size, mass, and function. Circulation 97: 569-575.

[16]. Matsubara M, Sato T, Nishimura T, Suzuki M, Kikuya M, et al. (2004) CYP11B2 polymorphisms and home blood pressure in a population-based cohort in Japanese: the Ohasama study. Hypertens Res 27: 1-6.

[17]. Miller SA, Dykes DD, Polesky HF (1988) A simple salting out procedure for extracting DNA from human nucleated cells. Nucleic Acid Res 16: 12-15.

[18]. Mornet E, White PC (1989) Analysis of genes encoding steroid 11-beta hydroxylase. (Abstract) Cytogenet. Cell Genet 51: 1047.

[19]. Nicod J, Bruhin D, Auer L, Vogt B, Frey FJ, et al. (2003) A biallelic gene polymorphism of CYP11B2 predicts increased aldosterone to renin ratio in selected hypertensive patients. J Clin Endocrinol Metab 88: 2495-500.

[20]. Prasad P, Tiwari AK, Kumar KM, Ammini AC, Gupta A, et al. (2006) Chronic renal insufficiency among Asian Indians with type 2 diabetes: I. Role of RAAS gene polymorphisms. BMC Med Genet 7: 42.

[21]. Purkait P, Raychodhury P, Bandhyopadhya S, Naidu JM, Sarkar BN (2013) Analysis of Aldosterone Synthase Gene Promoter (- $344 \mathrm{C}>\mathrm{T}$ ) Polymorphism in Indian Diabetic Nephropathy Patients. J Diabetes Metab 4: 271.

[22]. Rajan S, Ramu P, Shewade DG, Adithan C (2009) Promoter region polymorphism of CYP11B2 (344 C>T) gene in healthy volunteers of South Indian Tamilian population. Indian Journal Biotech 8: 358-362.

[23]. Rajan S, P. Ramu, G. Umamaheswaran, C. Adithan (2010) Association of aldosterone synthase (CYP11B2 C-344T) gene polymorphism \& susceptibility to essential hypertension in a south Indian Tamil population. Indian J Med Res 132: 379-385.

[24]. Russo P, Siani A, Venezia A (2002) Interaction between the C (-344) T polymorphism of CYP11B2 and age in the regulation of blood pressure and plasma aldosterone levels: cross-sectional and longitudinal findings of the Olivetti Prospective Heart Study. J Hypertens 20: 1785-1792.

[25]. Saidi S, Touhami Mahjoub, Wassim Y Almawi (2010) Aldosterone synthasegene (CYP11B2) promoter polymorphism as a risk factor for ischaemicstroke in Tunisian Arabs. Journal of Renin-Angiotensin-Aldosterone System 11(3): 180-6.

[26]. Schunkert H, Hengstenberg C, Holmer SR, Broeckel U, Luchner A, et al. (1999) Lack of association between a polymorphism of the aldosterone synthase gene and left ventricular structure. Circulation 99: 2255-60.

[27]. Sookoian S, Gianotti TF, Gonzalez CD, Pirola CJ (2007) Association of the C-344T aldosterone synthase gene variant with essential hypertension: a meta-analysis. J Hypertens 25: 5- 13.

[28]. Sookoian S, Gianotti TF, Pirola CJ (2008) Role of the C-344T aldosterone synthase gene variant in left ventricular mass and left ventricular structurerelated phenotypes. Heart 94: 903-910.

[29]. Stella P, Bigatti G, Tizzoni L, Barlassina C, Lanzani C, et al. (2004) Association between aldosterone synthase (CYP11B2) polymorphism and left ventricular mass in human essential hypertension. J Am Coll Cardiol 43: 265-70.

[30]. Tamaki S, Iwai N, Tsujita Y, Kinoshita M (1999) Genetic polymorphism of CYP11B2 gene and hypertension in Japanese. Hypertension 33: 266-270.

[31]. Tang W, Wu H, Zhou X, Cheng B, Dong Y, et al. (2006) Association of the C-344T polymorphism of CYP11B2 gene with essential hypertension in Hani and Yi minorities of China. Clin Chim Acta 364: 222-5.

[32]. Tiret L, Mallet C, Poirier O, Nicaud V, Millaire A, et al. (2000) Lack of association between polymorphisms of eight candidate genes and idiopathic dilated cardiomyopathy: the CARDIGENE study. J Am Coll Cardiol 35: 29-35.

[33]. Tsukada K, Ishimitsu T, Teranishi M, Saitoh M, Yoshii M, et al. (2002) Positive association of CYP11B2 gene polymorphism with genetic predisposition to essential hypertension. J Hum Hypertens 16: 789-93.

[34]. White PC, Hautanen A, Kupari M (1998) Aldosterone synthase (CYP11B2) polymorphisms and cardiovascular function. Endocr Res 24: 797-804.

[35]. White PC, Slutker I (1995) Haplotype analysis of CYP11B2. Endocr Res 21:437-42.

[36]. White PC (1994) Disorders of aldosterone biosynthesis and action. N Engl J Med 331: $250-258$

[37]. Yamagishi K, Tanigawa T, Cui R, Tabata M, Ikeda A, et al. (2007) Aldosterone synthase gene T-344C polymorphism, sodium and blood pressure in a free-living population: A community-based study. Hypertens Res 30: 497-502. 